\title{
Erkazancı Durmuş, Hilal. (2020). Pierre Bourdieu Sosyolojisi Işığında Türk Tiyatro Alanında Çevirinin Rolü ve Dostlar Tiyatrosunun Konumu. İstanbul: Hiperyayın, 166 s. ISBN 978-605-281- 841-1
}

Kitap tanıtımı/Book review

\section{Umut Can GÖKDUMAN}

Arş. Gör., Hacettepe Üniversitesi, Edebiyat Fakültesi, Mütercim-Tercümanlık (Fransızca) Bölümü, umutcangokduman@gmail.com, ORCID ID: orcid.org/0000-0003-0045-227X

Son yıllarda çeviri sosyolojisi araştırmalarında belirgin bir artış görüldüğünü söylemek mümkündür. Bununla birlikte Türkçe olarak kaleme alınan araştırmaların kısıtlı olduğunu belirtmek de yerinde olacaktır. Hacettepe Üniversitesi MütercimTercümanlık Bölümü öğretim üyesi Dr. Hilal Erkazancı Durmuş'un yapıtı bu anlamda Türkçe çeviri sosyolojisi alanyazınına yapılan önemli bir katkı olarak görülebilir. Yazarın ön sözde de değindiği üzere kitabın amacı tiyatro çevirisinin özelliklerini ve sorunlarını ele almak, çeviri incelemesi yapmak ya da çeviride karşılaşılan güçlüklere çevirmenlerin geliştirdiği stratejileri irdelemek değildir. Bu yapıtta, Fransız sosyolog Pierre Bourdieu'nün özellikle habitus, alan ve sermaye kavramlarından hareketle Türk tiyatrosunda çevirinin rolüne odaklanılmaktadır. İlgili kavramların açıklanması ve çeviribilime yansımaları kitabın ilk üç bölümünü oluşturmaktadır. Dördüncü bölümde Bourdieu'nün kavramlarından hareketle Türkiye'de çevirinin tiyatro alanındaki rolü irdelenmektedir. Son bölümde ise Genco Erkal ve Dostlar Tiyatrosu özelinde tiyatro alanına Bourdieu perspektifinden yaklaşılmaktadır. Her bölümün sonunda bölüm özeti şeklinde sunulan sonuç kısımları da yer almaktadır.

Birinci bölümde habitus kavramına sosyoloji alanında değinilmekte, çeviribilimde habitus kavramının yansımaları çeşitli araştırmacıların çalışmalarına atıfta 
bulunularak irdelenmektedir. Erkazancı Durmuş, habitus kavramının çeviribilimdeki konumunu, kavramın Gouanvic (1999, 2007), Inghilleri (2003, 2005), Sela-Sheffy (2005), Simeoni (1998) ve Wolf $(2006,2007)$ gibi araştırmacılar tarafından sıklıkla kullanılmasıyla ilintilendirmektedir (s. 25). Bu kavramın çeviribilim araştırmalarında "çevirmenin kılıcı rolüne ışık tut[tuğunun]" altını çizmektedir (s. 25). Çeviribilim araştırmalarında habitus kavramının kullanılmasına yönelik dikkat çektiği nokta biyografik çalışmalardan farklı olarak habitus incelemesinde "çevirmenin toplumla etkileşimin[in]" (s. 42) ön planda olmasıdır. İlk bölümün sonunda yer alan sonuç kısmında habitus kavramı ile sosyoloji alanındaki farklı kuram ve kavramların birleştirilerek kullanılmasının çeviribilime katkı sağlayabileceği vurgulanmaktadır.

İkinci bölümde, alan kavramı irdelenmekte, ilk bölümle benzer şekilde kavramın sosyolojide nasıl ele alındığına değinilmekte, ardından çeviribilimdeki yansımalarına odaklanılmaktadır. Burada Even-Zohar'ın çoğuldizge kuramı eleştirel bir yaklaşımla ele alınarak "çeviri sürecine katılan eyleyiciler tarafından oynanan rolün göz ardı edilmesi çeviri sürecinin basite indirgenmesine neden olabilir" (s. 51) tespitinde bulunulmaktadır. Çevirinin kendi oluşturduğu alana ise Michaela Wolf'un (2007) değindiği "özerklik, hiyerarşik bir yapılanma, alanda tanınmak ve kabul görmek için verilen mücadele ve mücadelenin alanı yeniden üretebiliyor olması" (akt. Erkazancı Durmuş, 2020, s. 56) temel koşulları sıralanarak vurgu yapılmaktadır. Sonuç kısmında, çeviriden bir alan olarak söz edilmesinin koşulları, çeviri eyleyicileri arasında yer alan hiyerarşik ilişkilerin sürekli olarak devam et(tiril)mesine ve eyleyiciler arasındaki mücadelenin daimi olmasına bağlanmaktadır.

Üçüncü bölümde Bourdieu'nün sermaye kavramı mercek altına alınmaktadır. Kavramın sosyolojideki yerinin açıklanmasının ardından ilk iki bölümde olduğu gibi çeviribilimde sermayenin nasıl irdelendiğine değinilmektedir. Yan metinsel ögelerin çevirmene simgesel sermaye kazandırabileceği vurgulanmakta ve çevirmenin sahip olduğu bu sermaye türünün "bir yazarın erek kültüre giriş yapmasını etkile[diği]" (s. 64) belirtilmektedir. Bu bölümde de Even-Zohar'ın çoğuldizge kuramına eleştirel bir yaklaşım söz konusudur. Erkazancı-Durmuş, ilgili kuramın "işlevselciliğe dayanan bir kuram" olduğunu ve kuramın "toplumda kılıcı rol oynayan kişi ve kurumlar yerine metinler üzerine yoğunlaş[tığını]" (s. 68) belirtmektedir. Bu bölümün sonuç kısmında ise farklı sermayelere sahip çevirmenlerin ülke ve dil bazındaki eşitsizliklerden etkilendiğinin altı çizilmektedir.

Dördüncü bölümde, ilk üç bölümde yer alan kavramlar kullanılarak Türkiye'de çevirinin tiyatro alanındaki rolüne odaklanılmaktadır. Erkazancı Durmuş, araştırmasını Cumhuriyet'ten önce batı tarzı tiyatro ve Cumhuriyet tiyatrosu şeklinde iki farklı dönem üzerinden gerçekleştirmektedir. Bu dönemleri de kendi içlerinde ayrıntılandırmaktadır. Cumhuriyet öncesi dönemde "özgün eserler yerine çeviri ve uyarlama eserler ağırlık kazanmıştır" (s. 75) tespitinde bulunurken Tanzimat Dönemi'nde tiyatronun devlet kontrolünde devam ettiğini ifade etmektedir. İlgili dönemde sansürün yazar ve çevirmenler için bir doxa oluşturduğunu vurgulamaktadır. Erken Cumhuriyet Dönemi'nde ise bu doxanın "oyunların sade ve anlaşılır bir Türkçe ile yazılmış veya çevrilmiş olması” şeklinde ortaya çıktığını belirtmektedir (s. 81). 60'lı yıllarda politik 
tiyatronun çeviri aracılığıyla yayıldığı vurgulanarak "çevirinin tiyatro alanının özerkliğini kazanmasında" önemli bir rol oynadığının altı çizilmektedir (s. 90). 80'lerde "toplumsal ve kültürel dönüşüme zemin hazırlayabilecek alternatif avangart oyunlar"ın (s. 97) tercih edildiğini ifade eden Erkazancı Durmuş, "ana akım tiyatro oyunlarının çevirisinin ön plana çıkması" (s. 98) konusunu da buna bağlamaktadır. Suratına (In-Yer-Face) Tiyatro oyunlarının da 90'larda Türkiye'ye giriş yaptığının altını çizmektedir. 2000'lerde, yerli oyunların Devlet Tiyatroları repertuvarına eklendiğine de dikkat çekmektedir.

Beşinci bölümde, ilk olarak Genco Erkal daha sonra ise Dostlar Tiyatrosu, sosyolojiden ödünçlenen kavramlarla çeviri sosyolojisi bağlamında mercek altına alınmaktadır. Erkazancı Durmuş, Erkal'ın habitusunu incelediğinde "profesyonel anlamda katkıda bulunduğu ilk oyundan itibaren, norm yıkıcı ve heterodoks bir söyleme sahip ol[duğunu] ve alanda egemen konuma direnç göstererek meydanokuma stratejisini izleyen oyunlarla ortaya çıktığını” (s. 114) belirtmektedir. Erkal'ın düşünceleri üzerinde Nâzım Hikmet ve Bertolt Brecht'in etkili olduğunu vurgulamaktadır. Dostlar Tiyatrosunun nasıl konum aldığını irdelemek amacıyla hangi yerli ve yabancı oyunların seçildiği ve bu oyunlarla ilgili söylemlerin ve toplumsal olaylara karşı alınan konumların incelenmesinin önem arz ettiğini belirtmektedir. Erkazancı Durmuş, bu Tiyatro'nun sahnelediği oyunların repertuvarının büyük bir kısmını politik oyunların oluşturduğunu, çevirilerin "Türk toplumunda düşünce ve ifade özgürlüğü gibi hassas konularla ilişkilendirildiğini ve bu ilişki çerçevesinde Türk toplumunda yaşanan gelişmelere paralel olarak uyarlamalar yapıldığını" söylemenin mümkün olduğunu belirtmektedir (s. 132).

Çevirinin dönüştürücü rolüne vurgu yapan bu kitap, müzikli bir oyun türü olan Batı tarzı oyunların, operetin, politik tiyatronun, Suratına (In-Yer-Face) Tiyatro oyunlarının çeviri yoluyla Türkiye'ye giriş yaptığını vurgulamaktadır. Erkazancı Durmuş, çeviri sosyolojisi bakış açısıyla Türk tiyatrosu özelinde çevirinin üstlendiği rolleri irdelemektedir. Yapıtın, çeviri sosyolojisi alanındaki araştırmacıların düşmemeleri gereken tuzaklara dikkat çektiği, dolayısıyla çeviri sosyolojisi araştırmacıları için bir kaynak olma özelliği gösterdiği ifade edilebilir. Çeviri sosyolojisi kavramlarının Türk tiyatro alanı üzerinden okunmasına fırsat sunan bu kitap çeviri sosyolojisi alanyazınına önemli katkılar sunmaktadır. 